\title{
THE APPLICATION OF PASSIVE SEISMIC TECHNIQUES TO THE DETECTION OF BURIED HOLLOWS
}

\author{
Michael G. Raines \\ British Geological Survey, Environmental Science Centre, Nicker Hill, Keyworth, Nottingham NG12 5GG, United \\ Kingdom,mgra@bgs.ac.uk
}

\author{
Vanessa J. Banks \\ British Geological Survey, Environmental Science Centre, Nicker Hill, Keyworth, Nottingham NG12 5GG, United \\ Kingdom,vbanks@bgs.ac.uk
}

Jonathan E. Chambers

British Geological Survey, Environmental Science Centre, Nicker Hill, Keyworth, Nottingham NG12 5GG, United

Kingdom, jecha@bgs.ac.uk

Philip E.F. Collins

Brunel University London, Uxbridge, UB8 3PH, United Kingdom, Philip.Collins@Brunel.ac.uk

\section{Peter F. Jones}

University of Derby, Kedleston Road Site, Derby, DE22 1GB, United Kingdom,

P.F.Jones@Derby.ac.uk

\section{Dave J.R. Morgan.}

British Geological Survey, Environmental Science Centre, Nicker Hill, Keyworth, Nottingham NG12 5GG, United

Kingdom,djrm@bgs.ac.uk

James B. Riding

British Geological Survey, Environmental Science Centre, Nicker Hill, Keyworth, Nottingham NG12 5GG, United

Kingdom,jbri@bgs.ac.uk

\section{Katherine Royse}

British Geological Survey, Environmental Science Centre, Nicker Hill, Keyworth, Nottingham NG12 5GG, United

Kingdom,krro@bgs.ac.uk

\begin{abstract}
Pilot studies involving the use of passive seismic techniques in a range of geological settings and applications, e.g., mapping bedrock, studies of soil erosion and Quaternary mapping have shown that it is a versatile, non-invasive and economic technique. This paper presents the findings of three case studies that trialled the use of passive seismic techniques for the detection and characterisation of buried hollows in carbonate rocks, comprising: i) a buried hollow in the Cretaceous Chalk at Ashford Hill in the Kennet Valley, a tributary of the River Thames, UK; ii) buried karst in the foundation excavations for wind turbines in Carboniferous Limestone at Brassington, Wirksworth, Derbyshire, UK, and iii) defining the extent of solution hollows that host terrestrial Miocene
\end{abstract}

deposits, near Friden, Newhaven, Derbyshire, UK. Whilst case studies ii) and iii) are focused on areas of buried dolines, the geological context of the Ashford Hill site is more complex; comprising a deformation hollow with an uplifted "pinnacle" of chalk bedrock at the centre. The data were collected using a (Tromino), a three-component, broadband seismometer to measure background ambient noise (microtremors induced by wind, ocean waves, industrial machinery, road and rail traffic, etc.). The Tromino is small, portable with an operating range of $0.1 \mathrm{~Hz}$ to $1,024 \mathrm{~Hz}$ and interpreted using proprietary software (Grilla), which subjects the data to Fourier transformation and smoothing. Where possible, estimated shear wave velocities used in the Grilla Software modelling, based on peaks identified on the $\mathrm{H} / \mathrm{V}$ spectrum, have been calibrated using 
borehole data or parallel geophysical techniques. In each case, the karst features were defined by Nakamura's horizontal to vertical $(\mathrm{H} / \mathrm{V})$ spectral ratio technique, where microtremors are converted to show impedance contrasts (velocity $\mathrm{x}$ density), or a pseudo layered seismic stratigraphy of the near surface along each profile. An additional benefit of the use of this technique is its depth of penetration and potential for defining the structural and lithological context of the hollows, thereby contributing to the process understanding associated with their formation. To this end the technique has helped define discontinuity (fault, joint or bedding) guidance of the hollows.

\section{Introduction}

In 2012 the British Geological Survey (BGS) acquired a modern passive seismic measurement unit (Tromino) to complement their existing suite of geophysical equipment. During the subsequent two years, this equipment has been tested in a range of geological and geomorphological settings. The Tromino measures passive seismic (acoustic, elastic wave) noise, which comprises both natural $(<1$ $\mathrm{Hz})$ and man-made $(>1 \mathrm{~Hz})$ frequencies, and extracts information from it through time domain and spectral techniques, i.e., HVSR (horizontal to vertical spectral ratio, Nakamura, 1989). The ratio of the averaged H/V frequency spectrum is used to determine the fundamental site resonance frequency and interpreted using regression equations to estimate the thickness and depth to bedrock. The instrument comprises a single, light-weight, mobile seismometer incorporating a compact 3-component electrodynamic sensor (velocimeter) with an operating frequency of between $0.1 \mathrm{~Hz}$ and $1,024 \mathrm{~Hz}$, above which, anelastic absorption resulting from rock internal friction causes strong attenuation (Castellaro et al., 2005). One advantage of the Tromino is the efficiency with which data can be collected. The duration of recording is scheduled in accordance with the lowest frequency of interest allowing for at least 10 repetitions to achieve stability and further time to allow for the variation in resonance with time. In practice this requires a recording time of $10-15$ minutes (Micromed s.p.a., 2009), but enables significant ground coverage within a day. The Tromino's operation is based on guidelines and recommendations made by the Site Effects Assessment using Ambient Excitations project (SESAME European Research Project, 2004). The instrument is placed on natural ground (artificial surfaces are more rigid and dampen the $\mathrm{H} / \mathrm{V}$ curve) and orientated parallel or orthogonal to linear features and structures, because of the polarization or directional resonance effects on ground motion. The technique is applicable where a soft layer overlies a hard substratum (e.g., Amorosi et al., 2008; Grippa et al., 2011). Interpretation of the results requires an understanding of a number of influential factors, e.g., the potential for trapped waves (waves without vertical penetration due to reflection); the increased complexity of the seismic response to irregular geometry in the basement deposit, or the presence of faults, cavities and irregularities in the topography (Panzera et al., 2013). Recorded data returns from the Tromino are analysed using Grilla software, which subjects the data to Fourier transformation and smoothing (Triangular Window method, Micromed s.p.a) to derive a plot of frequency against H/V, e.g., Figure 1. Interpretation of the results requires a measure of "shear-wave velocities", which can be obtained from the literature or from laboratory testing. Here we present three case studies undertaken in the context of karst geohazard research in the BGS.

\section{Case Study 1: Detection of a Buried Hollow at Ashford Hill, Hampshire}

Buried hollows encountered in the Chalk can be a hazard for construction in the London region where they comprise closed depressions that are associated with ground deformation and may be infilled with softened and/ or an unpredictable range of sediments (e.g., Banks et al., 2015). Some of the buried hollows in London extend deep into the bedrock geology and are in-filled with disturbed superficial deposits and reworked bedrock. They can be up to $500 \mathrm{~m}$ wide and more than $60 \mathrm{~m}$ deep. It is suspected that a "chalk pinnacle" (Hawkins, 1952) at Ashford Hill, approximately $100 \mathrm{~km}$ to the south-west of central London, provides a rural analogue for the London hollows. Consequently it became the focus for comparative Tromino and electrical resistivity geophysical surveys (Figures 2, 3, and 4) in a quest to identify successful non-intrusive tools for the identification of similar features elsewhere.

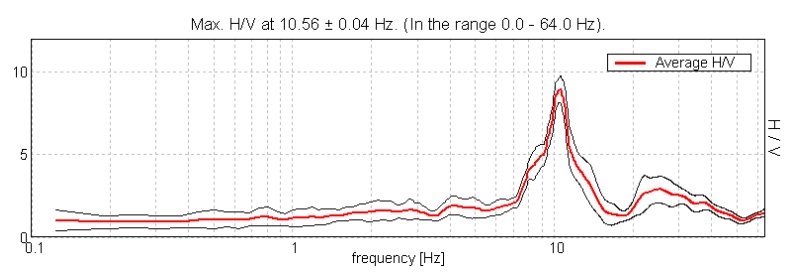

Figure 1. Typical H/V plot from case study 2 (Carsington Pasture). BGS@NERC. 2015. 


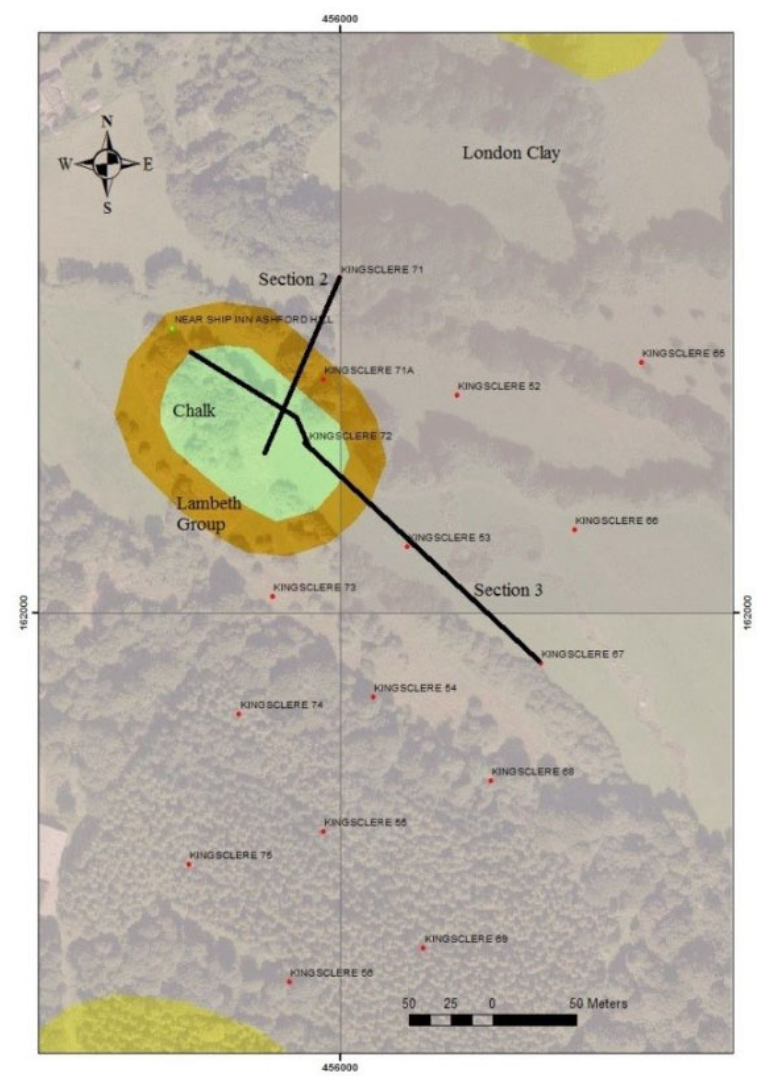

Figure 2. Case study 1: Context for Ashford Hill Tromino Section 3 showing geology and borehole grid (BGS, 2000). BGSONERC. Contains OS Open data (C)rown Copyright and database rights, 2015.

The isolated pinnacle of Newhaven Chalk (Cretaceous White Chalk Group) present at Ashford Hill is known to rise in the order of $50 \mathrm{~m}$ above its normal level. It is immediately surrounded by the stratigraphically younger Eocene Lambeth Group (interbedded shelly clays, clays, silty clays and silts that are underlain by black pebbly sands). The Lambeth Group strata (locally referred to as the Reading Beds) are overlain by the London Clay (Palaeocene Thames Group). This feature occurs in the buried valley of a tributary (Baughurst Stream) to the River Enbourne, itself a tributary of the River Kennet. In this setting alternative hypotheses were postulated with respect to the mode of formation, the principal ones being either as a consequence of confluence scour or due to synsedimentary subsidence (Collins et al., 1996). Within the valley, the bedrock geology is overlain by river terrace deposits and alluvium with patches of head deposits along the valley sides. The area is subject to flooding during periods of high groundwater levels (rising in the chalk) and the centre of the feature is largely covered by peat associated with a pool of standing water for much of the year. This unique setting warranted designation as a Site of Special Scientific Interest (SSSI) by Natural England in 1986. A series of boreholes was undertaken in the 1940s. The majority penetrated the London Clay and extended approximately $3 \mathrm{~m}$ into the underlying Lambeth Group which meant that the extent of the "pinnacle" was not fully constrained (Hawkins, 1952). The grid of boreholes formed the basis for the schedule of monitoring points for the Tromino (Figures 2 to 4 ) approximately $85 \mathrm{~m}$ apart. The electrical resistivity was undertaken along two lines

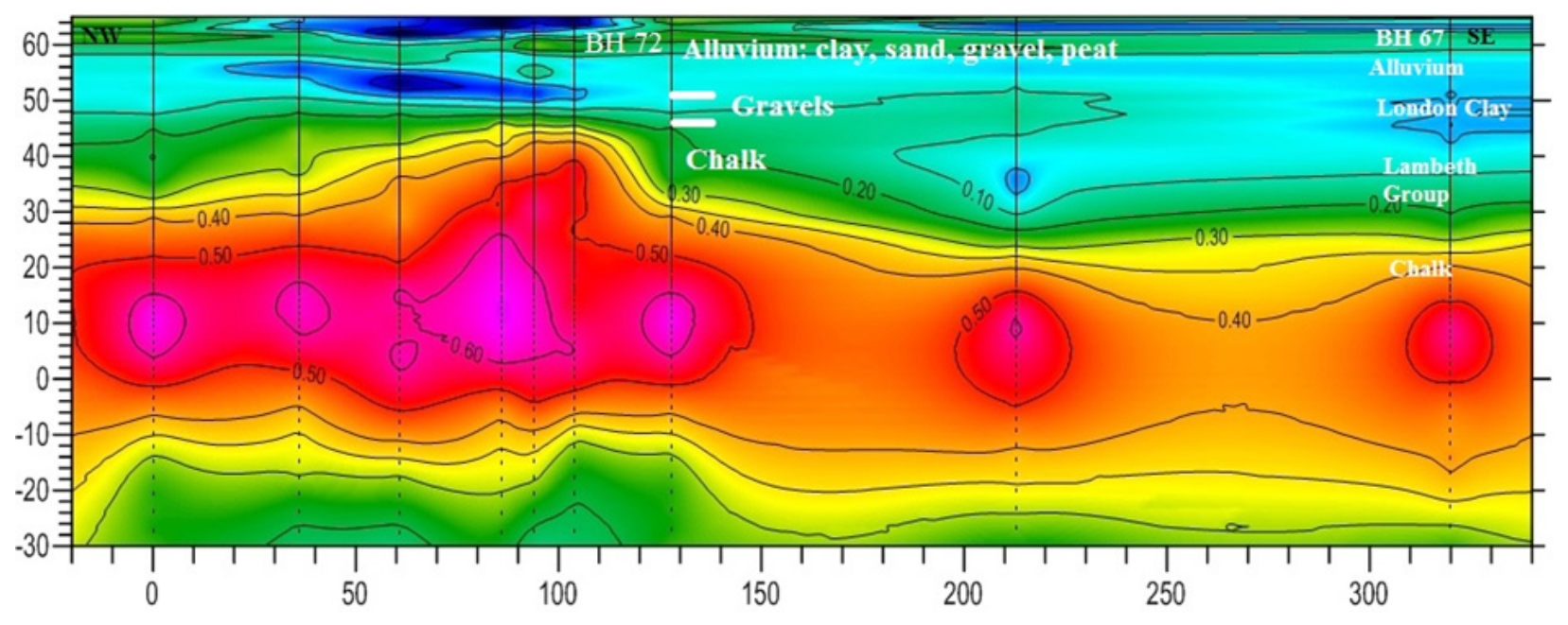

Figure 3. Case study 1: Ashford Hill Tromino Section 3 plot of impedance (H/V) against depth. BGSCNERC. 2015. 

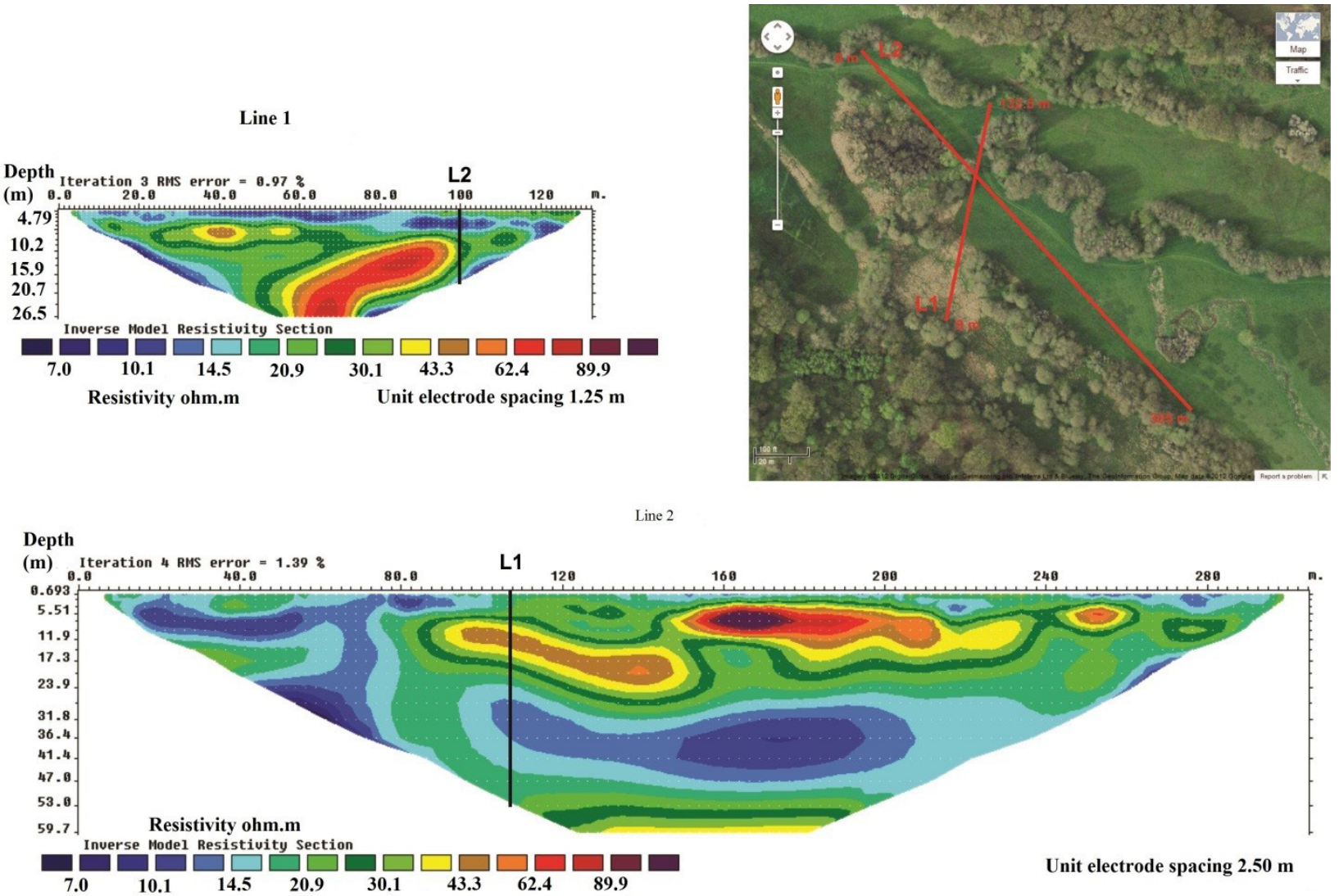

Figure 4. Ashford Hill Electrical Resistivity tomography survey. BGSCNERC. Contains OS Open data (c) Crown Copyright and database rights, 2015.

arranged approximately north-south and northwestsouth-east across the "pinnacle" (Figure 4). The H/V 0.4 contour and the low impedance characterising the organic alluvial soils. The "pinnacle" is mapped as an ovoid shape of approximately $120 \mathrm{~m}$ along the north-west axis and $80 \mathrm{~m}$ along the north-east axis on the 1: 50000 scale geological map. Tromino survey sections 2 and 3 (Figure 3) suggest that the feature is approximately $100 \mathrm{~m}$ by $40 \mathrm{~m}$. Comparison of the Tromino results with the electrical resistivity profiles (Figure 4) shows the benefits of using multiple techniques in geophysics, as each technique measures different properties. Whilst the Tromino provides valuable information with respect to the bedrock boundaries, the electrical resistivity provides good resolution in the near surface and is strongly related to the moisture content of the ground, e.g. the low resistivity associated with the high moisture contents in the vicinity of the chalk "pinnacle" towards the north-west end of line 2 and the northern end of line 1 (Figure 4).

\section{Case Study 2: Detection of Karst Encountered in the Construction of a Windfarm in the Peak District, Derbyshire, UK}

Excavation of the foundations for four wind turbines at Carsington Pasture, near Wirksworth, in the Derbyshire Peak District, UK exposed buried, sediment filled hollows in the bedrock. The hollows are attributed to a form of karst that results from hypogene processes on a carbonate platform edge. The bedrock geology (Aitkenhead et al., 1985) comprises dolomitised Carboniferous limestones that have been subject to lead-zinc-barite mineralization as a consequence of the expulsion of fluids from overpressurized mudstones that occupied the adjacent Widmerpool Gulf (Figure 5). The carbonate sediments are interbedded with thin layers of volcanic dust that have weathered to clay (wayboards). Infill sediments comprised variable mixes of vari-coloured silty clay, sand, sand and gravel and clayey sand (Jones and Banks, 2014). Excavation of the foundations commenced on May 8, 2012. Difficult ground conditions were encountered that 
necessitated remedial engineering measures and delayed the project by 12 to 14 months. This provided a time window within which it was possible to trial the Tromino in another karst setting.

At Carsington Pasture, Tromino surveys were carried out across two of the turbine foundation excavations (T1 and T2). Here we describe the profile across the excavation for T1. The BGS used the Tromino to measure the seismic noise at $5 \mathrm{~m}$ intervals along an approximately northerly alignment across the excavation for the foundation of Turbine 1 (T1, Figure 5). Recording times were limited to 8 minutes and ground elevations were determined using conventional levelling techniques. The configuration of the impedance contrasts (Figure 6) suggests lithological guidance on the distribution of the higher impedance ground (non-dolomitised limestone with a lower porosity) with displacement being indicative of the presence of a fault, as indicated by the subvertical linear zone of low impedance (Figure 6). This may be sediment filled and appears to be dissolutionally

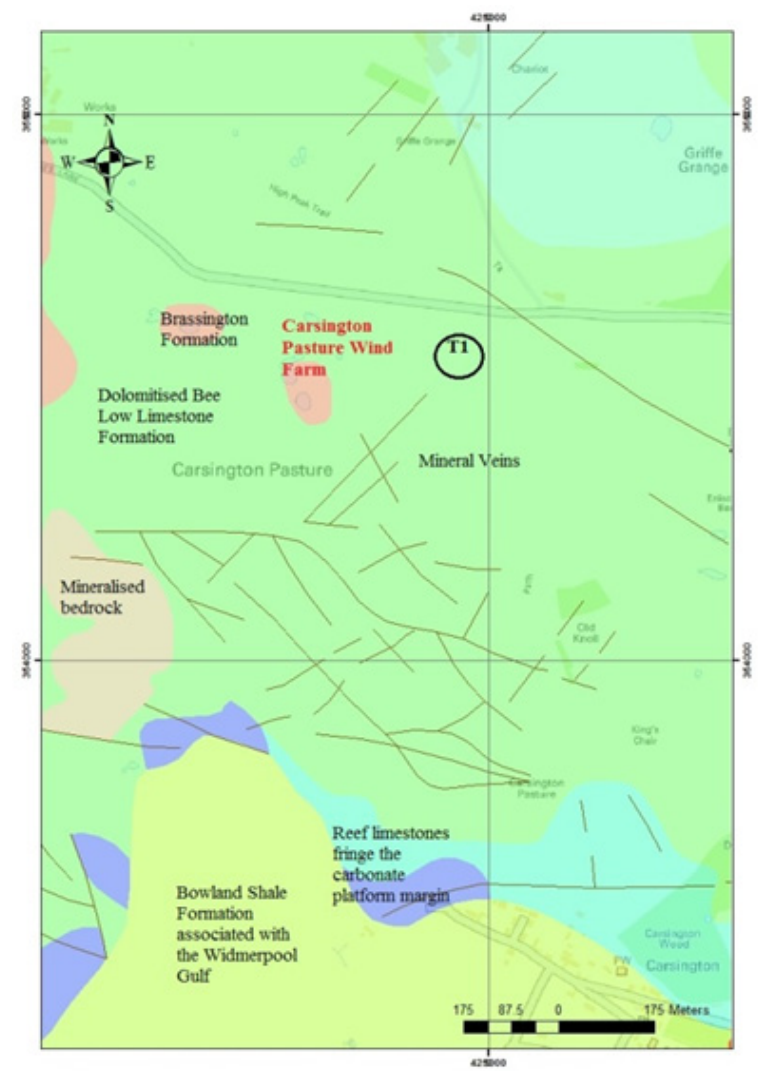

Figure 5. Case study 2: geological context for the Carsington Pasture survey (BGS, 1983). BGSONERC. Contains OS Open data (CCrown Copyright and database rights, 2015. enlarged, particularly at a depth of about $25 \mathrm{~m}$. Although there was no borehole evidence to validate these findings, their value was described by the Resident Engineer for the project as being representative of what was actually encountered during excavation for the remedial engineering measures $(10 \mathrm{~m}$ cut from the near surface zone of low impedance towards the southern end of the section and fill with imported crushed limestone). Panzera et al. (2013) concluded that it is not possible to identify a unique spectral response to cavities. It was noted that the response (amplification or deamplification of the vertical component of motion) appears to be influenced by cavity size such that only cavities having a height of greater than about $4 \mathrm{~m}$ show significant $\mathrm{H} / \mathrm{V}$ spectral peaks. Intrusive investigation would be required to validate the extent of the dissolutional enlargement evident in Figure 6.

\section{Case Study 3: Enhancing Geological Knowledge Associated with the Buried Hollows that Host Terrestrial Miocene Deposits in the Peak District, UK}

Terrestrial Miocene deposits are relatively rare in the UK and their preservation in deep hollows in the dolomitised limestone of the Peak District Carboniferous platform is of significant scientific interest in terms of the associated flora and implications for understanding the climatic

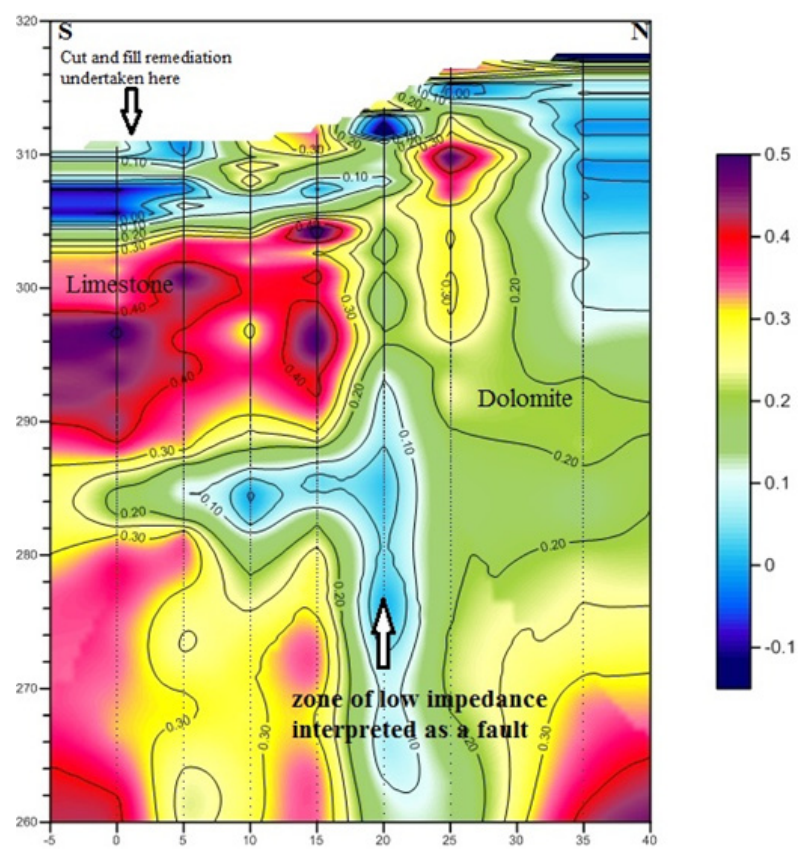

Figure 6. Impedance (H/V) against depth for northerly transect across T1. BGS@NERC. 2015. 


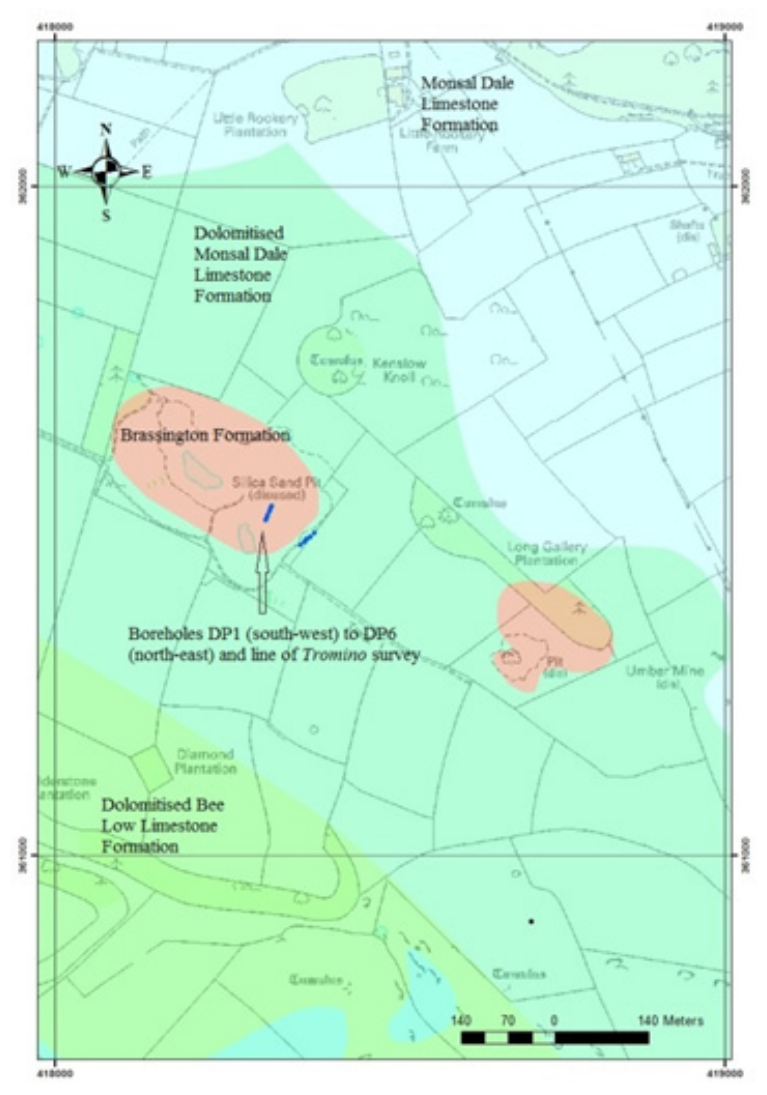

Figure 7. Geological context for case study 3: Kenslow Pit showing borehole locations (BGS, 1978). BGS@NERC. Contains OS Open data CCrown Copyright and database rights, 2015.

and environmental conditions at the time of deposition (Boulter et al., 1971; Pound et al., 2012). These deposits were formerly exploited for refractory minerals and many worked out excavations occur as a series of remnant depressions. Two depressions at Kenslow, near Friden in the Peak District, UK (Figure 7) became the focus for trialling the Tromino in a karst setting. At this location the bedrock geology comprises dolomitised limestone (Asbian age Bee Low Limestone Formation of the Peak Limestone Group). A series of borings that had previously been undertaken by the minerals company (borehole logs available via the BGS national geoscience data centre) provided a target for ground truthing of the larger pit.

The passive seismic noise was monitored at approximately $20 \mathrm{~m}$ centres, coincident with the former line of boreholes at the base of the pit. Recording times were limited to 8 minutes. The impedance plots were generated using a Vs value of $225 \mathrm{~m} / \mathrm{second}$, a typical value for sand. The configuration of the impedance contrasts (Figure 8) again suggests lithological guidance on the distribution of the higher impedance non-dolomitised limestone. In this profile a subvertical zone of high impedance is suspected to be indicative of a mineral vein, as borne out by the occurrence of barite in borehole DP1. This borehole encountered a void at $22.65 \mathrm{~m}$ depth, which can also be identified in the impedance plot (Figure 8).

\section{Conclusions and Potential for Further Development in Karst Environments}

Each of the three case studies demonstrates the value of using passive seismic techniques to establish the elevation of bedrock, which is particularly beneficial in karst terrains where knowledge of the depth to bedrock is critical for engineering design. The case studies include both softer Cretaceous Chalk and Palaeozoic limestone bedrocks. Case studies 2 and 3 indicate that passive seismic techniques appear to provide an efficient means of discriminating between lower impedance dolomitised and higher impedance non-dolomitised limestones in the platform carbonates in the Southern Peak District, UK. Faults and mineral veins have also been successfully identified using the Tromino. The implication is that this would be an effective technique for investigating the extent of buried karst in areas scheduled for development, particularly given the efficiency with which data can be collected. A useful extension of this project would be i) the trialling of the application of passive seismic techniques to characterise artificially filled buried hollows, e.g., landfill, and ii) the application of more closely spaced monitoring to

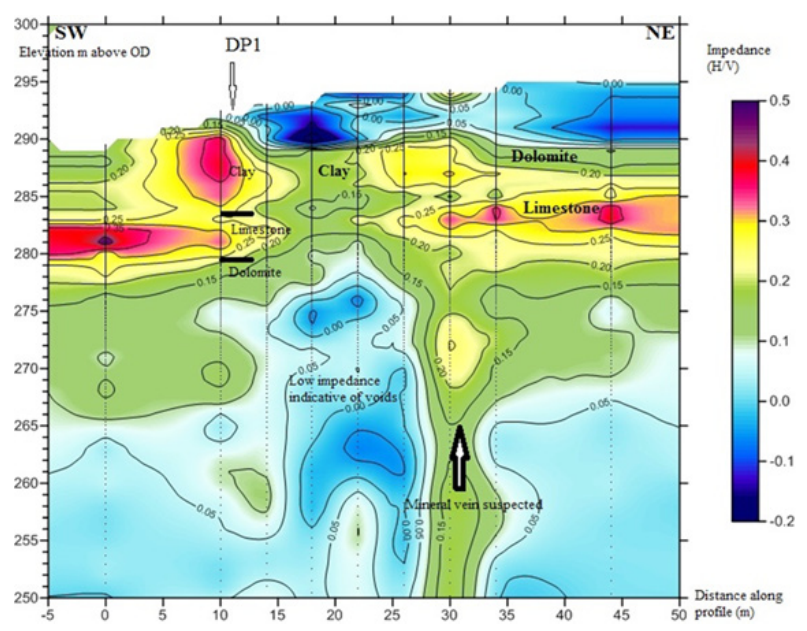

Figure 8. Impedance (H/V) against depth for a transect across the westerly line of boreholes in Kenslow Pit. BGSONERC. 2015. 
provide data to help constrain the processes associated with karstification. For each of the case studies, it is considered that the laboratory determination of shear velocities offers the potential for better modelling and resolution of depth in the superficial deposits.

\section{Acknowledgements}

The authors would like to thank: S. Castellaro for guidance and advice with respect to refining the interpretation of the Tromino results; Mrs J. Renwick for allowing access to Kenslow Pit; Carsington Wind Energy Ltd, West Coast Energy Ltd (GDF Suez) and Mr Roger Durrant (Raymond Brown Construction Ltd) for permission to investigate at Carsington Pasture, and Natural England for allowing access to the Ashford Hill site. Raines, Banks, Chambers, Morgan, Riding and Royse publish with the permission of the Executive Director of the British Geological Survey, NERC.

\section{References}

Aitkenhead N, Chisholm JI, Stevenson IP. 1985. Geology of the country around Buxton, Leek and Bakewell. British Geological Survey. HMSO. 168pp.

Amorosi A, Castellaro S, Mulargia F. 2008. Single-station passive seismic stratigraphy: an inexpensive tool for quick sub-surface investigations. GeoActa. 7: 29-39.

Banks VJ, Bricker SH, Royse KR, Collins PEF. 2015. Anomalous buried hollows in London: development of a hazard susceptibility map. Quarterly Journal of Engineering Geology and Hydrogeology. 48: 55-70. http://dx.doi. org/10.1144/qjegh2014-037.

Boulter MC, Ford TD, Ijtaba M, Walsh PT. 1971. Brassington Formation: A newly recognised Tertiary Formation in the Southern Pennines. Nature Physical Science. 231: 134-136.

British Geological Survey. 1978. 1: 50000 scale Geological Map 111. Buxton (Solid and Drift). NERC.

British Geological Survey. 1983. 1: 50000 scale Geological Map 124. Ashbourne (Solid and Drift). NERC.

British Geological Survey. 2000. 1: 50000 scale Geological Map 168. Reading (Solid and Drift). NERC.

Castellaro S, Mulargia F, Bianconi L. 2005. Passive seismic stratigraphy: a new efficient, fast and economic technique. Geologia Tecnica e Ambientale. 3: 76-102.

Collins PEF, Fenwick IM, Keith-Lucas DM, Worsley, P. 1996. Late Devensian river and floodplain dynamics and related environmental change in northwest Europe, with particular reference to a site at Woolhampton, Berkshire, England. Journal of Quaternary Science. 11 (5): 357-375.
Grippa A, Bianca M, Tropeano M, Cilumreiello A, Gallipoli MR, Mucciarelli M, Sabato L. 2011. Use of the HVSR method to detect buried paleomorphologies (filled incised-valleys) below a coastal plain: the case of the Metaponto plain (Basilicata, southern Italy). Bollettino di Geofisica Teorica ed Applicata. 52 (2): 1-16.

Hawkins HL. 1952. A pinnacle of chalk penetrating the Eocene on the floor of a buried river-channel at Ashford Hill. Near Newbury, Berkshire. Quarterly Journal of the Geological Society. 108: 233-260.

Jones PF, Banks VJ. 2014. Generating new geo-data. Geoscientist. 24 (8): 12-17.

Micromed s.p.a. 2009. The short Tromino how to. 30 pp.

Nakamura Y. 1989. A method for dynamic characteristics estimation of subsurface using mircotremor on the ground surface. Q.R. Railway Technology Research Institute Report. 30: 25-33.

Panzera F, Lombardo G, D’Amico S, Galea P. 2013. Speedy techniques to evaluate seismic site effects in particular geomorphologic conditions: faults, cavities, landslides and topographic irregularities. In: D’Amico, S. 2013. Engineering seismology, geotechnical and structural earthquake engineering. Intech Publishing. 300pp. http:// dx.doi/org/10.5772/55439.

Pound MJ, Riding JB, Donders TH, Daskova J. 2012. The palynostratigraphy of the Brassington Formation (Upper Miocene) of the southern Pennines, central England. Palynology. 36: 26-37.

SESAME. 2004. http://sesame.geopsy.org/SES Reports.htm. 
